\title{
Modernism and the Masks of History: The Novels of Paule Marshall
}

History can be apprehended only through its effects, and never directly as some reified force. This is indeed the ultimate sense in which History as ground and as transcendable horizon needs no particular theoretical justification: we may be sure that its alienating necessities will not forget us, however much we might prefer to ignore them.

-Fredric Jameson, The Political Unconscious

After struggling for some time, I was finally able . . . to bring together what I consider to be the two themes most central to my work: the importance of truly confronting the past, both in personal and historical terms, and the necessity of reversing the present order.

-Paule Marshall, "Shaping the World of My Art"

Against the grain of colonial modernism, which has sought to impose a single notion of history (one subordinated to European power) on the colonized space, Caribbean writers have often reverted to the culture of the subaltern to institute an alternative narrative of history, even an ideal history of the West Indian landscape. The result has been not only the kind of redefinition of history which I have discussed in previous chapters, but an attempt to establish-through the dynamics of deformation apparent in popular culture, minor characters, and black slaves-a distinctly Afro-Caribbean notion of modernism. Here, the act of narration acquires a political resonance akin to what Hous- 
ton Baker calls the "deformation of mastery": the subaltern subjects comprehend their social and cultural spaces "within their own vale/ veil more fully than any intruder" as they evolve a diasporic, indigenous language. Forms of popular culture, such as carnival and calypso, are enlisted to deform the rational discourse of European modernity; and, at the same time, the folk are introduced into the domain of cultural production "to refigure the very notion of 'culture' for the modern world."1

In almost every text discussed in the previous chapters, the colonial narrative of history is haunted by the popular folk version which it tries to repress. For example, in Lamming's Pleasures of Exile, vodun is the form in which the repressed returns to represent the unspeakable; in In the Castle of My Skin, the officially censored version of history breaks through the dream of the village elder $\mathrm{Pa}$, and the ancestral spirit, "speaking through the voice of an old man on the eve of his death, provides the kind of history which the village could not have learned from its official school." 2 Similarly, the poor and unrepresented in works as divergent as James's Beyond a Boundary and Carpentier's El siglo de las luces appropriate figures and artifacts of colonial culture, such as cricket and Catholic rituals, and turn them around through strategies of reversal and improvisation (amid instruments of Western culture), Baker says, "as a way of transforming such artifacts ... into resources for a world where mastery has been deformed."3

For Paule Marshall the transformation of the instruments of Western culture under the power and influence of the folk is a primary condition for the production of black culture in the New World. In her principal works, the folk return not only to disturb the dominant version of history and culture, but also to promote an Afro-American modernism that, by sustaining the tension between the persistent ancestral voice in black cultures and imposed European forms, seeks to affirm an indigenous language of history and self in the space of the other while unraveling the ideological and political necessity that justifies a Caribbean narrative. In Marshall's novels, as Edward Brathwaite succinctly observes, "we find a West Indies facing the metro-

1. Houston A. Baker, Jr., Modernism and the Harlem Renaissance (Chicago: University of Chicago Press, 1987), pp. 51 and 66.

2. George Lamming, "Introduction," In the Castle of My Skin (New York: Schocken, 1983), p. xvii.

3. Baker, p. 66 . 
politan west on the one hand, and clinging to a memorial past on the other. Within this matrix, she formulates her enquiry into identity and change." 4

Moreover, the question of how to represent and understand colonial modernism and its narrative of history is of the utmost importance to Marshall; it provides the ideological and theoretical underpinning for most of her major works. If her texts seem to keep on returning to the terms by which the colonized can articulate the past, it is because she believes that the present order of oppression and reification can only be reversed if its material conditions - and what she might consider to be the necessity of history-are fully comprehended. But Marshall's novels are unique in another sense: they probe the rules by which the black experience in the New World can be interpreted and represented. These novels struggle with the linguistic and psychological blockage that hampers the hermeneutical act, the rules of overdetermination that often make it impossible for the reader to gain access to those original meanings that have been repressed in the middle passage of the black experience. Marshall's major works thus strive to provide a metacommentary on the painful coexistence of European modernist institutions and the dynamic survivals of the African experience in the islands. In addition, Marshall's subjects often make narrative turns toward the Caribbean landscape in an attempt to capture what she aptly calls "thoughts and feelings about the Middle passage," and to elaborate "the psychological damage brought on by history." 5

Although Marshall perceives history in terms of its effects rather than as what Fredric Jameson, in the epigraph above, calls "a reified force," her novels-like those of her contemporary George Lamming - also strive to unmask the necessity of alienating history and even to provide a theoretical justification for an alternative episteme. Indeed, underlying Marshall's well-known concern with the nightmare of history and its alienating necessities is the desire for an ideal (and hence modern) version of the black experience which both transforms African culture and transcends the colonial tradition. History causes pain and suffering for Marshall's subjects, but as I argue in this

4. Edward Brathwaite, "West Indian History and Society in the Art of Paule Marshall's Novel," Journal of Black Studies 1 (December 1970), 227. According to Brathwaite, Marshall's incisive understanding of Caribbean modernism is probably due to her "partial" relation to the West Indian culture of her ancestors: "Had Paule Marshall been a West Indian, she probably would not have written [The Chosen People]. Had she not been an Afro-American of West Indian parentage, she probably could not have written it either" (p. 227).

5. Paule Marshall, "Shaping the World of My Art," New Letters 40 (October 1973), 110. 
chapter, the alienation occasioned by this history is a necessity because it triggers the cultural response that, in the words of Sylvia Wynter, "had transformed the New World Negro into the indigenous inhabitant of his new land."6 The roots of Caribbean modernism can actually be traced to the paradoxes and contradictions Wynter recognizes in the Africans' attempts to adapt themselves to the Caribbean landscape while transforming its nature:

\begin{abstract}
Out of this relation, in which the land was always the earth, the centre of a core of beliefs and attitudes, would come the central pattern which held together the social order. In this aspect of the relation, the African slave represented an opposing process to that of the European, who achieved great technical progress based on the primary accumulation of capital which came from the dehumanization of Man and Nature. . . . The African presence, on the other hand, 'rehumanized Nature,' and helped to save his own humanity against the constant onslaught of the plantation system by the creation of a folklore and folk-culture. ${ }^{7}$
\end{abstract}

In effect, folklore and popular culture played a central role in the transplanted Africans' quest for an indigenous language that could help them transcend reified history. According to Wynter, "Folklore was the cultural guerrilla resistance against the Market economy." 8 This resistance constitutes a key subtext in Marshall's novels: it is represented by the stories told by Barbadian emigrants in Brown Girl, Brownstones, the indigenous carnival sustained by the peasants of Bournehill in The Chosen Place, the Timeless People, and the national dances of Carriacou replayed by the displaced descendants of African slaves in Praisesong for the Widow. Whereas colonial history is represented as painful and alienating, a servant of the plantation system and the market economy, the voices of the subaltern affirm the history of the Africans, and the forms that history takes, as the "absent cause" that is shaping a Caribbean national culture.

\title{
The Political Unconscious
}

Simple issues of meaning -in particular the process by which individual subjects develop a material understanding of their conditions of

6. Sylvia Wynter, "Jonkonnu in Jamaica: Towards the Interpretation of Folk Dance as a Cultural Process," Jamaica Journal 4 (1970), 35.

7. Wynter, p. 36.

8. Wynter, p. 36. 
existence-constitute an important prelude to the larger historical questions that mark Marshall's novels. For example, the central motifs in Brown Girl, Brownstones - the mirror and the body-are intended to raise phenomenological questions about vision and representation. Confused and threatened by the harsh logic of Western materialism, Selina often struggles to define the meaning of her body, to even understand her own subjectivity. Her disjunctive relationship with the acquisitive world of her mother is often manifested in the division she feels between herself and her family. The ethic that drives her mother has no reality for Selina-indeed, her growth is stifled by the mother's insistence that the acquisition of material things is a manifestation of one's subjectivity. On the contrary, Selina's existence is defined by exclusion and an acute sense of the unreal.

A significant representation of the resulting repression of selfhood comes early in the novel when Selina reflects on the family photograph "which did not include her": "She wanted suddenly to send up a loud cry to declare herself." 9 Because this family icon does not include Selina, she believes that it has no reality for her; it is "the picture of a neat, young family and she did not believe it" (p. 7). Selina's world is one of illusionary and shifting figures without a center of significance: the family photograph signifies connections with an ancestral home in Barbados, but she does not belong there any more than she belongs to her mother's brave new world in New York. Since her father is the only person who appears real in the family portrait, Selina expects him to provide a link to the ethics and impulses of the ancestral past: "For her, he was the one constant in the flux and unreality of life" (p. 8). But for the father, like all the other Barbadian immigrants who populate Marshall's novel, connections to the past are at best tenuous; instead of functioning as a source of certainty and true understanding, the past often generates fear and shame. For example, Selina's father fears that Suggies's codfish will "insinuate itself into his clothes and he would carry it with him all night as the undisputable sign that he was Barbadian and a foreigner" (p. 22). And while her mother celebrates the Caribbean past in her stories and language, she also believes that in New York the success of her family can only be secured if the past and its ethics are rejected or modified.

When the past is celebrated in its pastness but rejected as anach-

9. Paule Marshall, Brown Girl, Brownstones (New York: Feminist Press, 1981), p. 6. Further references are in the text. 
ronistic in the drive for modernity, as my discussion of The Chosen Place, the Timeless People indicates, selfhood continues to be a contentious issue for the black subject even in a postcolonial situation. Moreover, the uncertainty of self which often haunts Marshall's characters functions as a metaphor of a larger crisis of historiography in her novels. Her characters are driven by a double, and often contradictory, movement: on one hand, they want to write themselves into the scheme of things and to be recognized by the dominant other as subjects with a culture and history; but, on the other hand, they believe that their mastery of the codes of the dominant cultureespecially wealth, property, and status-will guarantee their autonomy and integrity in a hostile world. The end result, however, is a process of repression, disguise, and self-division.

In Brown Girl, Brownstones, self-division is apparent in Selina's painful quest for subjectivity, her struggle to walk the tightrope between her mother's desire to be assimilated into the materialist ethic and her father's dream of returning to Barbados. When the mother forces Selina to wear "throw-offs," which the little girl perceives as symbols of her own alienation in her mother's mortgaged world, it is the father's "voice" which restores her to her own sense of self (p. 11). But as we saw in previous chapters, the repressed or marginalized Caribbean self can never find wholeness and deep meanings in the world of the other; because this self cannot belong wholly to the other's scheme of things, it must live as a fragment of both its culture and the value system of the dominant. For this reason, there is often a disjunction between the soul and the body in Marshall's text. In moments of despair, anger, and an acute sense of betrayal, Selina realizes that all her efforts to secure the integrity of her inner self have come to naught because "she was not free but still trapped within a hard flat body" (p. 62). The body belongs to the other-the dominant culture, her mother, the Barbadian community-and thus her attempts at transgression and self-engenderment are bound to fail.

The problem of self-identity in situations of displacement is further accentuated by the fact that one cannot develop a synthesis between the real (black) self and an assimilated self which might mask and protect the former. Self-division does not restore authority to one part of the self; on the contrary, it nullifies all the different entities that struggle within the divided self, and there is confusion about which self is authentic and which is merely figurative. The struggle for an authentic self, amid the travail of double consciousness, characterizes 
the quest of Jay Johnson in Praisesong for the Widow. Frustrated in his previous attempts to master the rules of the dominant white culture (even after a painful process of self-education he will not get a job as an accountant because of his race), Jay sets out to destroy his spontaneous and natural self and to adopt the hard, cold logic of "progress" as a tactic for survival. But what is the meaning of this new self? What are its values and how is it to be interpreted? For his wife, Avey, who was responsible for nudging him toward this change in the first place, the new Jay is "like the vague, pale outline of another face superimposed on his, as in a double-exposure."10

Now, a doubly exposed image has no clear outline; it exists as a fragment of two things without the representative value of either. So, in the end, Jay is defined by distance and difference from the things that were supposed to mark his new selfhood, including a suburban home. Significantly, in striving to be the equal of the other, Jay has repressed his individual utterance: "The voice was clearly his, but the tone and, more important, the things he said were so unlike him they might have come from someone ... who had slipped in when he wasn't looking and taken up residence behind his dark skin; someone who from remarks he made viewed the world and his fellow men according to a harsh and joyless ethic" (p. 131). Throughout the text, we could always identify the old Jay because of the similarity among his self, voice, and tone; in the new Jay, on the other hand, there is marked tension between voice and tone. Indeed, Jay's voice has now become a mask of his self rather than its signifier.

The persistent image of the veil or mask in Marshall's works denotes the impossibility of developing an essentialist sense of self and of truly knowing the colonized subject. The inaccessibility of the black subject is not always a negative condition, however, for as Baker has noted, the mastery of the mask "constitutes a primary move in Afro-American discursive modernism."11 Moreover, the African mask signifies the deep meanings that the colonial economy of representation relegates to the margins and contains within it what Henry Louis Gates has called "a coded, secret, hermetic world, a world discovered only by the initiate." 12 For instance, in The Chosen Place, the Timeless People,

10. Paule Marshall, Praisesong for the Widow (New York: Dutton, 1984), p. 131. Further references are in the text.

11. Baker, p. 17.

12. Henry Louis Gates, Jr., Figures in Black: Words, Signs, and the "Racial" Self (New York: Oxford University Press, 1987), p. 167. Many studies of masks have explored the correlation between masking, identity, and selfhood. Theodore Thass-Thienemann has, in fact, defined 
the mask idiom reflects the most complex hermeneutical codes and rules for understanding the world of the black peasantry. Trying to understand a character such as Ferguson is like trying to read a mask; first we must question our preconceived rules of interpretation: "Everything about him was overstated, exaggerated. His face, his neck, his clean-shaven skull, had the elongated, intentionally distorted look of a Benin mask or a sculpted thirteenth-century Ife head. With his long, stretched limbs he could have been a Haitian Houngon man. Or Damballa."13 The masked figure merges forms from Africa with those invented in the diaspora; in the process, new meanings about self, history, and culture are created. Such meanings are further enhanced, through paradox, by a neat balance between disguise and intelligibility. On the surface, Ferguson is presented as a deformed figure, but through this deformation he is connected to African masks and hence to a tangible black referent. And so Marshall invites us to read history as distorted and disguising, but at the same time fixed and deep.

Indeed, in The Chosen Place, which is one of the monumental texts on modernization and colonial historiography in the Caribbean, the central questions all subjects have to confront sooner or later have to do with representation and interpretation-how do we penetrate the disguise to tap the deep meanings of an alienated history and culture? Most of the characters in the book have to struggle to develop new modes of knowledge in a world in which the old relationship between master and slave, the colonizer and the colonized, has been reconfigured in the period of decolonization. More important, the middle passage of black culture is represented as a modern discursive space in which historical and other meanings cannot be taken for granted. In effect, the text postulates the problems, and possibilities, of recovering the most hidden meanings of a culture that has always used duplicity and self-masking as weapons of survival.

Nothing illustrates this interpretative problem as vividly as Saul's travail as he tries to understand the island of Bourneville. As a scholar,

masking as the quest for an objective way of looking at selfhood; see The Interpretation of Language, vol. 2 (New York: Jason Aronson, 1973), p. 55. See also Andreas Lommel, Masks: Their Meaning and Function (New York: McGraw-Hill, 1972), and Walter Sorell, The Other Face: The Mask in the Arts (London: Thames and Hudson, 1973). African masks and their poetics are discussed in Franco Monti, African Masks (London: Paul Hamlyn, 1969), especially pp. 15-23; Leon Underwood, Masks of West Africa (London: Alec Tiranti, 1964); Dennis Duerden, The Invisible Present: African Art and Literature (New York: Harper, 1975), p. 131.

13. Paule Marshall, The Chosen Place, the Timeless People (New York: Vantage, 1984), p. 121. Further references are in the text. 
Saul is a fervent believer in the Weberian doctrine of modernization as a rational process that liberates the self from restrictive traditions, but nothing in the American anthropologist's previous education or experience has trained him to understand the Caribbean subaltern's modes of representation and cultural production. ${ }^{14}$ Saul heads a research study of Bourneville, which is predicated on the belief that rational knowledge is the key to historical and social transformation, but for most of the text he is forced to spend time reflecting on the inadequacy of his own modes of interpretation which seek to rewrite the Caribbean landscape in terms of the Western metanarrative on progress and material wealth. Witness how the proposed anthropological study of Bourneville is represented in the methodical and dead language of economic and social modernization:

The proposed plan for Bourneville, as outlined during the talks at the Center prior to their departure, was to be done in three stages. There would be a preliminary study of six months to a year to obtain a general picture of life in the district as well as to discover why a number of other projects previously attempted there had failed. Once this was completed, the second or action phase of the work would begin with an expanded research team and one or more demonstration projects. [P. 51]

Once he encounters the island, however, Saul discovers that rational knowledge cannot measure up to the fleeting nature of reality in Bourneville; here the traditional and predictable oppositions (tradition/modernity, past/present) which sanction social analysis are quickly invalidated because the unconscious side of history determines the lives of the islanders more than Saul had expected. Thus in his attempt to "read" the island, Saul is confronted by realities he cannot fix in a temporal or historical scheme: "He could be struck by the feeling, too fleeting to grasp, that he had stumbled upon a world that was real, inescapably real, yet at the same time somehow unreal; of the present but even more so of the past" (p. 216).

It is clear that the signs and figures that denote this "illogical" mode of representation - the motionless figures of the cane cutters and the "ancient windmills" - negate all the key assumptions in the Center's modernist discourse. Indeed, if we accept Jean-François Lyotard's

14. See David Kolb, The Critique of Pure Modernity (Chicago: University of Chicago Press, 1986), pp. 3-10. 
famous definition of the modernist imperative as the drive "to seize and systematize the world and so liberate human possibilities by mastering the conditions of life in a cognitive and manipulative system,"15 then the admixture of the real and unreal which Saul encounters in the island undermines all notions of systematization embedded in his education and ideology. In other words, the binary oppositionsreality/illusions, past/present, and tradition/modernity-which the researchers hoped to establish conclusively to master the conditions of life in the island, are nullified by the "marvelous" reality of Bourneville, which does not allow for such oppositions.

There is an even more important consequence to this collapse of binaries-the rational authority of the analyst is put into question when the analysand refuses to fit into the former's preconceived models, which are then shown to be inadequate because they were fashioned elsewhere. Saul's frustration grows when he begins to realize that the "real" meaning of the island is actually inaccessible to him and that the unconscious (or irrational) side of knowledge has more authority than his rational scheme. Although his research is going well and he and his assistant Allen are collecting impressive data about Bourneville, "he could not rid himself of the feeling that something about the place was eluding him, some meaning it held which could not be gotten at through the usual methods of analysis" (p. 215). Furthermore, not even his rational mind is immune from the power of the imaginary: "He was letting his imagination get the better of him, he told himself, seeking more in things than was there . . . and he couldn't help feeling as the weeks came and went vaguely surrounded by a mystery, and he became increasingly puzzled, even annoyed. Something, goddamn it, he swore to himself, about the place was being withheld, hidden from him" (p. 216).

Saul's interpretative quest-his modernist desire for a master narrative for Bourneville-mirrors Marshall's textual and cultural desire for a metadiscourse that will "bring together all the various strands (the word is synthesis) and thus make of the diverse heritage a whole."16 Wholeness and synthesis, however, do not come easily to Marshall or her characters. Despite the authoritative narrative voice that promises a coherent narrative in The Chosen Place, the text is marked by an inner anxiety about meanings; the authority of characters, as interpreters of

15. Quoted by Kolb, p. 257.

16. Marshall, "Shaping the World," p. 106. 
culture and history, is either compromised and questioned by their personal doubts and crises of selfhood, or is unsettled by the tension between their desire for solid and complete meanings and the historical discontinuity that surrounds them. Thus Merle Kinbona has struggled for eight years to make sense of the history of the island, to resurrect the hidden and unofficial history of her people-which is built around the myth of Cuffee Ned and his slave revolt-only to discover that such a discordant and subversive history is not easily written into the master text of colonial history: "Saul could see how the lonely eight-year search for coherence and vision had exhausted her" (p. 229). Rather than seeking a coherent set of meanings-a historical and even linguistic deep structure-beneath the fragmentary reality, Marshall's text eventually returns to history itself not to provide solutions to the problem of interpretation and representation in a colonial world, but to provide a metacode of Caribbean history itself, to provide what Jameson calls (in another context) "a commentary on the very conditions of existence of the problem itself."17

\section{The Nightmare of Colonial History}

What is the reality of the colonized (black) self? What are the original and forgotten meanings of its experience and how can they be recovered? Within the context of modernist discourse, people like Saul begin their Caribbean experience with the belief that the subject does not create its meanings, but uses its interpretative powers to recover preexisting meanings. For such Weberian modernists, to use David Kolb's formulation, "modern identity is not just another in a sequence of historical constructs; it is the unveiling of what has been at the root of those constructs." 18 To his horror-but eventual satisfaction-Saul finds that during his research in Bourneville he has not been unveiling preexisting meanings but basically rewriting the island to reflect his own "personal meanings" (p. 217). He soon discovers, as does the reader, that the narrative of history can be established not by a general appeal to an original experience but through an act of projection in which the subject rewrites the past to reflect its own desires. In the

17. Fredric Jameson, "Metacommentary," in The Ideologies of Theory: Essays 1971-1986, vol. 1 (Minneapolis: University of Minnesota Press, 1988), p. 5.

18. Kolb, p. 10.

178 
process of narration, the subject realizes that history, instead of being the crucible of fixed meanings, is a source of disorder and neurosis. As Merle Kinbona concludes after eight years of trying to decipher its meanings, Caribbean history is so displaced and so disturbing that we should avoid its study altogether; only then can we insulate ourselves from its pain: "Ah, well, ah, history. ... Any of you ever studied it. . . . Well, don't if you haven't. I did it for a time-West Indian history it was and I tell you, it nearly, as we say in Bourneville, set out my head. I had to leave it off. It is a nightmare, as that Irishman said, and we haven't awakened from it yet" (p. 130).

Merle's passionate invocation of James Joyce's notion of history as a nightmare is not uncharacteristic of other characters in Marshall's novels: in her major works subjects are often haunted by their sense or knowledge of history; an encounter with the past creates a sense of betrayal and often ends in bitterness because this is a past of pain and loss. But if these characters see history as a nightmare, it is because they often start from a false premise - the belief that a "return" to the past, to ancestral sources, is an encounter with the heroic and monumental side of the black experience and that knowledge of this positive polarity, the better side of an often rapacious and dehumanizing existence, will become an antithesis to the reification that characterizes the present moment. In the end, however, Marshall's texts represent history as the object that blocks desire and fixes subjects and communities in reified positions. In other words, history is a ruse: it promises one thing but delivers another. Yes: history appears in Marshall's texts as deceptive, divergent, and full of contradictory meanings; it also comes loaded with predetermined images that tell us more about those who read and write it than about its actual "original" meaning.

The allegory of history often begins as an architectural process, complete with monuments that supposedly represent the "timeless place and the chosen people," but the effects of this process are ironic and fragmented. Consider the meaning of the brownstones in Brown Girl: for many of the Barbadian immigrants in New York, these buildings have become the very embodiment of the American dream, the objects of desire at the end of an eschatological process in which hard work leads to wealth and happiness. However, a closer reading of these monuments of social uplift and desire shows how Marshall has loaded the brownstones with meanings that reverse their overt intentions.

If the ownership of a brownstone is the mark of self-engenderment, 
the notion that the owners of the brownstones have subjectified themselves by acquiring property is undermined by the buildings' uniformity: "They all shared the same brown monotony. All seemed doomed by the confusion of their design" (p. 3). Each of the brownstones is supposed to be distinctive to emphasize the individuality of their owners, but this individuality in style is already suspect: "Looking close, you saw under the thick ivy each house had something distinctively its own. Some touch of Gothic, Romanesque, baroque or Greek triumphed amid the Victorian clutter" (p. 3). And this is precisely the problem of the modernity project in relation to the identity and heritage of the Caribbean subject: it draws fragments from different European styles, but it does not fuse them into a new, redesigned form; hence the confusion that has doomed the social meaning of the brownstones even before their owners have paid for them. Furthermore, if the right to property has now been posited as signifying self-engenderment-and is hence conceived as a source of pleasure and fulfillment-the ivy that covers the buildings (all were "draped in ivy as though in mourning") is a symbol of death and decay. The buildings, like history itself, are hence fated to cause disappointment and hurt. ${ }^{19}$

Similarly, for many subjects in The Chosen Place, history hurts not only because the experience of the middle passage is painful, but also because the values and cultures submerged during the crossing from Africa to the Americas cannot be recovered holistically. Therefore, those characters such as Merle Kinbona who desire wholeness from this history are condemned to live with the yawning gap between their desire and the temporal situation; history, like modernism, is an incomplete project. Indeed, very early in the novel, history and the temporal experience are represented to us solely as fragments, ruins, or remnants of something buried so deep in time that its true value and form can never be established. More specifically, the history of the postcolonial state which, as I have argued in earlier chapters, was supposed to mark a break with the colonial past, is shown to be nothing but a shoddy, old-fashioned replica of the old order of things.

19. For a study of history as an "absent cause" that causes suffering and disappointment see Fredric Jameson, The Political Unconscious: Narrative as a Socially Symbolic Act (Ithaca: Cornell University Press, 1981), p. 102. See also Deborah Schneider, "A Feminine Search for Selfhood: Paule Marshall's Brown Girl, Brownstones," in The Afro-American Novel since 1960, ed. Peter Bruck and Wolfgang Karrer (Amsterdam: Gruner, 1982), pp. 53-74; Kimberly Benston, "Architectural Imagery and Unity in Paule Marshall's Brown Girl, Brownstones," Negro American Literature Forum 9 (Fall 1975), 67-70. 
In the first part of the book (appropriately titled "Heirs and Descendants" because it is concerned with the genealogy of modernity in the Caribbean), the ruins of history appear in various guises: Merle's Bentley is the former state car of the colonial governor, "but the car had been badly used since then, and was now little more than a wreck"; her body, too, "had begun the slow, irreversible decline toward middle age" (p. 4). A succession of motifs reinforces this image of decay, decline, and incompleteness: Merle's dress and decorations are fragments from diverse cultures; their beauty is obvious, but their meaning is indeterminate:

\begin{abstract}
All this: the dress with its startling print, the strange but beautiful earrings that had been given to her years ago in England by the woman who had been, some said, her benefactress; others, her lover; the noisy bracelets, the shoes-all this could be easily taken as an attempt on her part to make herself out to be younger than she was. But there was more to it than one sensed. She had donned this somewhat bizarre outfit, each item of which stood opposed to, at war even, with the other, to express rather a diversity and disunity within herself, and her attempt, unconscious probably, to reconcile these opposing parts, to make of them a whole. Moreover in dressing in this manner, she appeared to be trying (and this was suggested by those unabashedly feminine shoes) to recover something in herself that had been lost: the sense and certainty of herself as a woman perhaps. There was no telling. But her face, as she stood breathing angrily down at the muddy swill at her feet, attested to some profound and frightening loss. [P. 5]
\end{abstract}

Several points in this description need to be underscored: First, the representation of the subject is cast in a rhetoric of doubt, exemplified by the divided opinion over Merle's relationship with the English woman (was she her benefactress or her lover?). The narrative gives us perspectives (or voices) which are not sanctioned by the narrator and hence have no authority at all. Second, a set of important qualifiers ("all this could be easily taken ..."; "somewhat bizarre ...") leave the reader in a state of doubt about the meaning and value of Merle's actions: why does she dress the way she does? We are not sure. Finally, by foregrounding Merle's sense of uncertainty-both about "herself as a woman" and as a character in history-the narrative ensures that we can never accept her as Marshall's "center of consciousness."

In the paragraph that follows, Merle's face is refigured as a mask that has been despoiled "much the same way as the worn hills to be 


\section{WRITING IN LIMBO}

seen piled around her on all sides had been despoiled"; this face is a sign of historical denial- "something of great value had been taken from her" (p. 5). However, there is an important duality in this temporal loss: worn out by time, the mask has acquired the status of an antique and its "vital center remained intact": "This sense of life persisting amid that nameless and irrevocable loss made her face terribly affecting, even beautiful" (p. 5). When we eventually try to make sense of the history of Bourneville, we will have to learn how to describe not only the worn-out surface, but also the inner core, for the meaning of the past seems to lie in a strange conjunction of loss and survival. And there is a prior question, too: do the ruins that confront us on the surface of Bourneville have any value as historical signs?

In his famous discussion of the allegory of history, Walter Benjamin asserts that ruins provide the guise for history, "and in this guise history does not assume the form of the process of an eternal life so much as that of irresistible decay." More important, the ruin appears "as the last heritage of an antiquity which in the modern world is only seen in its material form, as a picturesque field of ruins." 20 The ruin or remnant in The Chosen Place is intractable and conceals a sinister past. Take, for example, the room that houses the nightclub in Bourneville: it is described as a "long, high nave, wholeareas of which were lost to the shadows dwelling beyond the reach of the touring lights" (p. 81). But the room is just the visible part of something more important. "It occupied the second story of a former sugar warehouse" and if you dug beneath the warehouse, you would possibly discover the slave barracoons: "The rusted remains of the iron manacles that had been fitted around the ankles and wrists, around the dark throats, could still be seen, some said, in the walls of the cellar. It had all begun here" (pp. 81-82). With this kind of antiquity, the island appears as a picturesque jumble: "All the discards of the nations, all the things that had become worn out over the centuries or fallen into disuse might have been brought and piled in a great charnel heap here" (p. 82). Elsewhere, Bourneville is often compared to "a ruined amphitheater whose other half had crumbled away and fallen into the sea," and to "some halfruined coliseum" (p. 99).

Ultimately, history in The Chosen Place is shown to be a dialogical process that takes many forms, operates on diverse levels, and is often

20. Walter Benjamin, The Origin of German Tragic Drama, trans. John Osborne (London: NLB, 1977), p. 178. 
the source of contention. Merle is fired from her teaching job because she insists on teaching the history of the repressed: "She was telling the children about Cuffee Ned and things that happened on the island in olden times, when the headmaster wanted her to teach the history that was down in the books, that told all about the English"' (p. 32). There are differing philosophies of history, too: Vere is entrapped in a history that takes the form of repetition; he returns to the islands from the United States expecting things to have changed, only to discover that "nothing had changed. He had been foolish to imagine that it ever could, this being Bourneville" (p. 35). In contrast, Allen Fuso's research is propelled by an Aristotelian confidence in the rational doctrine that allows "everything, including people" to be put in "their proper categories" (p. 15); on the opposite end of the spectrum are the poor people of Bourneville who believe in the performative power of history. Merle, too, shares this faith in the performative function of history: when she retells the history of Cuffee Ned, we are told, "her voice held the awe of someone viewing it for the first time" (p. 101). At one point, the narrative contrasts performed history (retold by Merle) with Allen's "scrupulously objective" rendering of the same history according "to the historical records" (p. 102).

In all cases, Marshall's subjects are involved in a quest for a metadiscourse to justify their actions or rationalize their place within the scheme of things established by colonialism or the postcolonial state. ${ }^{21}$ This appeal takes different forms, but it is often crystallized in a binary opposition between, on one hand, an appeal to wealth and material progress and, on the other hand, an evocation of the spirit of history. Thus, in Brown Girl, Selina's life is influenced and shaped by the tragic opposition between Deighton Boyce's yearning for deep historical meanings and his wife's rejection of the Bajan past in favor of the success ethic. Similarly, the drive to create wealth becomes the most important source of legitimacy for Jay Johnson in Praisesong, and is contrasted to the final quest for the meaning of the spirit of black history which engages Avey Johnson at the end of the novel.

In The Chosen Place, Marshall confronts both the limits and possibilities of colonial modernity and eventually proffers a dramatic contrast between the rational discourse of modernism and the claims of an-

21. On the relationship between modernity and metadiscourse see Jean-François Lyotard, The Postmodern Condition: A Report on Knowledge, trans. Geoff Bennington and Brian Massumi (Minneapolis: University of Minnesota Press, 1984), p. xxiii. 
cestral meaning. As we have already seen, the rational discourse of modernism in this novel is associated with Weberian scientists such as Saul and Allen; their empirical study of Bourneville is intended to systematize knowledge so that the individual subject can be liberated from the "tyranny" of the past. Although these investigators scrutinize and analyze the objects of the past and the present, their temporal investment is in the future. If a unified knowledge of Bourneville as a whole can be established, they reason, then the island can be transformed as a whole.

The important point to stress here is that both analysts and their objects are uneasy about the past; they live in fear of the unknown history of the island and their own individual histories which they have carefully repressed or masked. Indeed, the researchers' sponsoring organization, the Center for Applied Social Research (CASR), uses its modernizing mission as a mask for some shameful economic activities by its financial backers, including active involvement in the slave trade (p. 37). So, in many ways, what the modernizing project proposes as a movement away from the past has deep roots in a history it would like to, but cannot, deny. For Marshall, then, the benevolent phase of late capitalism is just another face of the Caribbean mercantile and plantation system, which created most of the problems the modernizers are trying to solve. Although it has posited itself as the agency for historical transformation, CASR is, at the same time, shown to be linked to the very foundations of Caribbean slave society. Thus the new modernism promoted by this agency is exposed as a repetition of an equally dubious modernist movement in Caribbean history-the institution of the culture of sugar and slavery.

Implicit in such historical instances of repetition and reversal is a discursive irony that is crucial to Marshall's deconstruction of the modernists' claim to represent a new relationship with time. The manners and world view of the new ruling class in the island suggest that they are the agents of change and transformation, but their utterances to this effect are always undermined by a subtle subtext reminding the reader that these individuals have already been fixed by the old, colonial economy of meanings. The "surface ease and charm" of the new Caribbean elite cannot entirely mask the fact that "in spite of their secure air, they were not altogether sure that the relatively new affluence and position they had come into were truly theirs" (p. 53). In spite of the nationalism that veils it, modernity is just a continuation of the European vision of history imposed on the island during the 
colonial period. Lyle Hurston's "imposing white house" is a synecdochal representation of the uneasy and duplicitous nature of Caribbean modernity: the house appears to be modern, but it is really built on the remains of an old Georgian house; it retains the ugly elements of the latter though it tries to conceal them under a "profusion of modern touches that were suspect." The house, concludes the narrator, "was a failure, although this was not immediately apparent, and most people thought it handsome, progressive and new. But the designer, in trying to blend the old and the new, had failed to select the best from each-those features from the past and present which would have best served his end" (p. 54). And so the present bears the baggage of the past even against its will.

Here Marshall is posing important questions hinted at variously in the other texts I have examined: Why does independent Caribbean society try to sustain the affirmative character of European culture even as it rejects colonial domination? Why is the mask of modernity so valuable to the maintenance of power and domination in the independent state? Indeed, why does Hurston, as a representative of the native ruling class, promote a discourse of resistance against colonial ideologies even as he helps reinforce and rebuild the institutions of colonialism? The theoretical response to these questions has been provided by Louis Hartz, who argues that members of the "creole" ruling classes in the New World require their European origins or modes of knowledge "to rationalize their class position."22 In Marshall's text, this class inscribes its difference from the ordinary people of Bourneville by insisting on the ways in which their mastery of European forms has legitimized their position as agents of modernity and modernization. The assumption here is that the general populace cannot effect change; Bourneville's people "don't take easy to anything new, even when it might be to their good" (p. 158). In contrast, the "creole" elite can effect change by "breaking the old pattern of depending on the outside for everything. ... Once we industrialize on a large enough scale we will then have means to finance the changes needed in agriculture" (p. 206). This is how an old colonial modernity comes to wear a nationalist mask. ${ }^{23}$

22. Louis Hartz, The Founding of New Societies (New York: Harcourt, 1964), p. 11.

23. According to Jean Franco the magic of modernity is an attempt to control the past to show postcolonial peoples "how much better off they are in the present"; in this sense, "the modern state is a kind of illusionist which needs the past only as a lament and whose miracle is the economic miracle of dependency." See "The Nation as Imagined Community," in The New Historicism, ed. H. Aram Veeser (New York: Routledge, 1989), p. 206. 
Both the foreign and native modernists in the novel privilege their ideology by appealing to three theoretical positions: the mastery of the discourse of modernism and the belief that they are the only ones amenable to historical change; the assertion of a vision of history which is supposed to be "true" and "right" because it is contained in documents and is invested with the idea of progress; and the representation of island society as a unified whole, one that does not allow for social, class, and race differences or for different political articulations. Both Saul and Allen invest in empiricism because they hope to established a logical explanation for social change. This logic is predicated on the suppression of the irrational and the unconscious, the magical and the romantic. Ironically, it is not Saul and Allen who master Bourneville; on the contrary, the island brings out the repressed in both characters-Allen's homosexuality and Saul's empty love life.

And if the reader is looking for a dramatic confrontation between the ideal of progress and repressed histories, Vere's life and death provide the example. For like many other characters in Marshall's novels - those who subscribe to what I have been calling modernityVere is always in search of techniques of dédoublement. He feels anachronistic within the island culture, finds it difficult to reconcile himself to its immobility, and yearns to engender himself differently: his restoration of the old Opel is nothing less than a test of his capacity for subjectivity. But the young man's belief that he can express his character and identity through the technical mastery of the machine is contrasted to his aunt's rejection of the rational notion that human beings have power over the instruments they use: "It was as though she believed beyond question that all such things as cars, all machines, had human properties, minds and wills of their own, and those were constantly plotting against those whom they served" (p. 185). Ultimately, Vere's death in the car (pp. 366-67) seems to be enough proof that there are important Caribbean meanings that are closed to Western knowledge and technology.

\section{The Longing for the Ideal of History}

In his influential discussion of the relationship between history and literature, Glissant makes the following comment on the Caribbean writer's desire for the "ideal of history": 
The passion for or the preoccupation with history does not manifest itself in the writer as a need for a reserve of information to which he has easy access, not as a reassuring framework, but rather as the obsession with finding the primordial source toward which one struggles through revelations that have the peculiarity (like myth in the past) of obscuring as well as disclosing. ${ }^{24}$

Carnival and the carnivalesque function in The Chosen People as a "primordial source" that obscures as well as discloses: they suspend time and mask the drudgery of everyday life while also functioning as expressions of the peasants' desire for an alternative means of organizing history and language. For outside observers, the carnivalesque is obscure; for the peasants of Bourneville, it discloses a collective genealogy and perpetuates their "national" spirit. Through their subversive interpretation of the official carnival masque, these peasants adopt the carnivalesque as an alternative narrative of history, one in which ancestral memories can be retained and the ideology of colonial modernism can be contested. Carnival, as Hortense Spillers has argued in her superb reading of the novel, is Marshall's "master sign and controlling figure." 25 Indeed, the poor people of Bourneville establish their mastery of language by adopting the minstrel mask, the weapon of the trickster and of black modernism. ${ }^{26}$ These peasants are hence compared to Anancy, the trickster in Afro-Caribbean folklore, who "though small and weak, always managed to outwit the larger and stronger creatures in his world, including man, by his wit and cunning" (p. 224). The subterranean and subversive space provided by the carnivalesque is introduced in the text to challenge the dominance and ideology of colonial modernism by dispersing the authority of meanings imposed from above.

Because carnival has become ossified into a commodity-it is a major tourist attraction in the island - the peasants must also strive to maintain its original meanings to secure their own subjectivity. In the

24. Edouard Glissant, Caribbean Discourse: Selected Essays, trans. J. Michael Dash (Charlottesville: University Press of Virginia, 1989), p. 79.

25. Hortense J. Spillers, "Chosen Place, Timeless People: Some Figurations on the New World," in Conjuring: Black Women, Fiction, and Literary Tradition, ed. Marjorie Pryse and Hortense J. Spillers (Bloomington: Indiana University Press, 1985), p. 165. See also Peter Nazareth, "Paule Marshall's Timeless People," New Letters 40 (October 1973), 113-31; and two articles in CLA Journal 16 (September 1972): Leela Kapai, "Dominant Themes and Technique in Paule Marshall's Fiction" (49-59) and Winifred L. Stoelting, "Time Past and Time Present: The Search for Viable Links in The Chosen Place, The Timeless People by Paule Marshall" (60-71).

26. Baker, p. 17. 
end, however, the carnival functions as a space where conflicting versions of history meet. The upper classes and the tourists see the carnival as a meaningless spectacle that creates a temporal suspense that is useful because it represses class, racial, and caste differences. Lyle Hurston describes it as "a marvelous sight, and a much needed one ... . in a world where all of us manage to be so ugly to each other, especially over this whole stupid question of race and color" (p. 200). But Hurston's interpretation of the carnival is overdetermined by his equivocal position within the culture: as the representative of Bourneville in the legislature, he has one foot in the "native" culture; but as a privileged member of the neocolonial elite, he has his other foot in the colonizer's Anglo-Saxon culture. In the latter position, he views the carnival from without, as a spectacle that mirrors his own desire to master and control his people, or to mediate the relationship between the margin and the center.

The real spirit of carnival as a mode of social expression, as Mikhail Bakhtin argues eloquently in his famous study of Rabelais, derives from the fact that the people don't view it as a spectacle, but "live in it, and everyone participates because its very idea embraces all the people."27 In fact, the peasants of Bourneville position themselves within the carnival and subject themselves to the gaze of others and even the contempt of the rest of the community because they view the masque as an expression of their world view and sense of self and hence insist on representation in their own terms. ${ }^{28}$ As Harriet puts it aptly in a letter to her friend Chessie, "For some reason people in Bourneville insist on enacting the same masque or story every carnival, which is against the rules. But they say it's cheaper, because then they don't have to buy new costumes" (p. 233). Unable to grasp the importance of this adherence to old meanings, and exasperated by the peasants' failure to modernize their masque, the rest of the island tries to bar the poor people of Bourneville from the carnival altogether. Furthermore, the reason the people of Bourneville give for their failure to change their routine is obscuring. In reality they have made the conscious decision to challenge the carnival as a depository of official truths and to inscribe their own narrative of history within the dominant culture.

27. Mikhail Bakhtin, Rabelais and His World, trans. Helene Iswolsky (Cambridge: MIT Press, 1965), p. 7 .

28. According to Rex Nettleford, the festival is "a positive expression of people's worldviews and sense of self." See "Implications for Caribbean Development," in Caribbean Festival Arts, ed. John Nunley and Judith Bettelheim (Seattle: University of Washington Press, 1988), p. 196. 
Against the grain of modernity-which values the future more than the past, change and transformation more than myth and ritual-the peasants promote a narrative built on repetition and changelessness. They feel that the new carnival, as an official spectacle, has become institutionalized in the capitalist system of exchange; by insisting on changelessness, these people have defied the logic of neocolonialism and its investment in the future.

Moreover, if the official carnival gestures toward the colonial notion of a single history, the peasants' masque foregrounds the ambiguity of historicism. Although their obsession with the past is seen by other members of the community as a form of escapism, by marching against "the rules" the people of Bourneville are in keeping with the true spirit of the original carnival, which celebrated the revolt of the slaves. Thus the people of Bourneville insist not only on repeating the masque of the previous year, but also on replicating the worn-out history of the Cuffee slave rebellion; to the embarrassment of the rest of the island, they come "dragging into town every year in the same old rags, looking $s$ ' bad and embarrassing decent people with some old-time business everybody's done forgot" (p. 283). In contrast, the new island elite, by using the carnival to celebrate their notions of modernization, are seeking relief from the past and its responsibilities. Furthermore, instead of becoming commodities in the carnival, the peasants use the carnivalesque as a subversive force that, to borrow Bakhtin's terms, celebrates "temporal liberation from the prevailing truth and from the established order." 29

But this investment in the past-and hence in the notion of history as a form of repetition-runs counter to Bakhtin's description of carnival as "the true feast of time, the feast of becoming, change and renewal." 30 In temporal terms, the question Marshall poses here is not whether carnival celebrates change or affirms old values; rather, she is concerned with probing the value of a history that repeats itself. In the process, she seems to suggest that a recovery of the past contradicts the neocolonialists' claim to have restored the spirit of the modern nation through the mastery of imperial discourses. In contrast, the repetition of unofficial and incomplete histories, such as the Cuffee Ned revolt, is a reminder that we have not yet been reconnected to the past, that our modernity and our modern "national culture" are 
achieved through the repression of the slave tradition of resistance. Thus the masque that the peasants of Bourneville repeat over and over again is not simply the Freudian repressed that returns to haunt us, nor merely the unconscious of history; rather, it is also an attempt to capture and articulate the voice of the black subject in the categories of its own modernity.

Consequently, the voice plays a prominent part in the Bourneville masque. At the end of the march, we are informed, the voices of the peasants rise as if from the depths of time, breaking through the ragged costumes that had masked the power of sound. "And the effect of that sudden uprush of sound, coming as it did after the numbed silence, was of a massive shock wave upon the air, and once again, New Bristol seemed to reel at its base" (p. 286). The voices resurrect the past and return us to the fixed scene of Caribbean beginnings, a scene determined by what Spillers calls "origins that must be appeased, at least recognized and named out loud." 31 Moreover, the value of repeated history is shown to lie in its deep play: those who seek the mere spectacle in the Bourneville masque will only see old and worn-out costumes and hear tired and sour words; but those who listen carefully will sense a "deeper level of consciousness . . . moving beneath its static surface" (p. 410).

At the end of the carnival, even the modernizers are forced to revise both their modes of interpretation and their conception of temporality. For example, Saul, who had earlier advocated modernization as a decisive break with tradition, now realizes that the past cannot be disavowed; ignored by generations of conquerors and rulers, the peasants of Bourneville perform the past to keep it alive, and in the process strive "to come into their own, start using their history to their own advantage" (p. 315). Repetition is hence a form of reterritorialization; the past is shown to be alive while time is momentarily stopped so that the lessons of history may not be lost. The carnival masque has rejected the Anglo-American desire to move the colonial subjects into the future without first addressing the past. In this respect, the carnivalesque is a way of turning temporality inside out, thereby "telescoping whole centuries so that events which had taken place long ago and should have passed into history and had been forgotten seemed to have occurred only yesterday-time had had a stop" (p. 414). In Marshall's own words, the people of Bourneville have refigured the

31. Spillers, p. 158. 
concept of time itself- "they seem apart from the Western notion of time altogether and as much a part of the past as the present. They might have been the rebel slaves who had refused to die. They might have been the original Africans who survived the crossing." 32

Marshall's notion of temporal continuity is only possible, however, because of a painful paradox embedded in the idea of the carnivalesque: the carnival masque suspends time so that the participants can celebrate their tradition of resistance; but once the festival is over, the characters have to return to a fragmented and disjunctive world that represses the very freedoms articulated in the feast. There is no doubt that Marshall and her characters seek an essentialist African voice in the New World and that her texts are concerned with the forms and conditions in which the black diaspora has carried on the sounds and words of ancient African traditions and "the oral mode by which the culture and history, the wisdom of the race had been transmitted." Yet the quest for an African voice has to confront the larger imperial discourses established by European modernism. ${ }^{33}$ The anxiety of Caribbean history and the West Indian longing for the ideal of history are most explicit in the conflict between the African voice and European colonial discourse.

Like other Afro-Caribbean writers-most notably Glissant and Brathwaite-Marshall often posits the voice as a paradigm for the repressed African past in Caribbean and Afro-American cultures. ${ }^{34}$ For example, in Brown Girl, Silla Boyce may strive to master the culture of capitalism and its celebration of property rights, but she cannot escape from the tradition of the voice that relives the past at every opportunity. For this reason, she has become "the collective voice of all the Bajan women, the vehicle through which their former suffering found utterance" (p. 45). This emphasis on the collective utterance would seem to suggest that the voice functions as a metaphor of the communal self or the allegory of its historical experiences. Indeed, when Mary Helen Washington asserts-in an excellent afterword to the novel-that Silla is "the avatar of the community's deepest values and needs" (p. 313), she assumes that the woman's voice and that of her community are identical, that there is a deep correspondence between voice, self, and community. And yet most of the novel is

32. Marshall, "Shaping the World," p. 111.

33. "Shaping the World," p. 103.

34. Edward Kamau Brathwaite, History of the Voice: The Development of National Language in Anglophone Caribbean Poetry (London: New Beacon Books, 1984), and Glissant, pp. 120-33. 
about the disjunction between Silla and her community. While Silla's voice often echoes many of her people's fears and hopes, it is also marked by its différance from what could be considered the traditional Bajan ethos. Indeed, one of the central questions raised by the book is this: to what extent does the Bajan culture retain its integrity once it has become caught up in the ethics of North American capitalism?

It is more accurate to argue that Silla's voice signifies the metonymic displacement of the Bajan culture in New York: she retains traces of the original voice, but as her disdain for her husband indicates, the original must be transcended for the sake of "progress." Indeed, Silla is placed in a paradoxical situation: her voice echoes the past while her actions question the ethics inherent in that past and its traditions. No wonder Selina hears her mother's voice as the figuration of the paradoxes of Caribbean cultures dispersed from their source- "the mother's voice was a net flung wide, ensnaring all within its reach. She swayed helpless now with its hold, loving its rich color, loving and hating the mother for the pain of her childhood" (p. 46). The voice from the past contains both joy and pain; it ensnares and liberates at the same time. ${ }^{35}$ Within the larger context of the African experience in the New World, the voice signalizes the slaves' history of loss and repression and, in many instances, the impossibility of recovering the African ideal or its idiom. For although such an ideal is desirable because it promises an alternative mode of representation, African culture in the Americas is already invested with the pain of Western history.

Marshall foregrounds this problem in the epigraph to The Chosen Place, a Tiv proverb that posits words as masks of historical hurt. And in the self-division in Merle Kinbona's voice, and the haunted echoes of the past in "the chosen place" itself, we have examples of how the voice represents the struggle between the utopian ideal of African synchronism and synthesis in the New World and the nightmare of Western history which places innumerable obstacles between the self and its desires. As a result Merle's voice is marked by an interesting duality: on one hand, this voice appears as the thing that represents her subjectivity (her personality is often identified by the way she talks); but, on the other hand, the narrative often stresses the extent to which this voice also masks a hidden and enigmatic self. In fact, Merle's voice appears to have acquired a life of its own, glancing off the

35. Marshall, "Shaping the World," pp. 98-101. 
surface, out of control, refracting from its origins and drawing our attention away from the speaker. Very early in the novel, Merle's voice is shown caught up in "what seemed a desperate downhill race with itself" (p. 11). Her words flow unchecked, "the voice rushing pell-mell down the precipitous slope toward its own destruction" (p. 66); this voice is variously described as "desperate" (p. 67) or "anguished" (p. 92). As the novel progresses, however, we begin to realize that the voice masks an inner pain; Merle's surface talk ("it was the talk, you sensed, which alone sustained her") is a form of temporal suspense, almost akin to the carnival masque. By talking, Merle postpones confronting the past; as she admits, "if I was to ever stop talking that'd be the end of me" (p. 96).

The quest for the ideal of history also foregrounds a crisis of interpretation and self-understanding in the black tradition as it tries to adjust to the demands of the dominant culture. For example, in Praisesong for the Widow, Avey Johnson's crisis of identity is closely related to her uneasy relationship to the "black voice" and her past. Her material success and co-option into the modern system of exchange have ostensibly liberated her from her past, but even as she begins to enjoy this success-this Weberian liberation from tradition, as it were-the past seems to become more difficult to deal with. The past returns to haunt her with the power of an "eternal recurrence" that threatens the very foundation of her success-the belief that she has transcended her complex ancestral past. The notion of "eternal recurrence" in Marshall's text is connected to the larger question that concerns us here, namely, the notion of an American, or more specifically an Afro-American, hermeneutics, anchored not on the traditional modernist belief in the future as a moment of closure in which meanings are revealed, but on the past as the site where such meanings are initiated. Two concepts-the "ring shout" and the "circle of meaning" - are important to Marshall's revision of Western temporality in Praisesong.

In writing about the ring shout and the circle of culture in his monumental study of slave society, Sterling Stuckey has argued that African slaves in the plantations of the Americas posited the circle and the ring shout as an allegory of "African autonomy," marking the set of values and symbols which could condition the interpretation of the black experience as distinct from the system that sought to annihilate it: 
The South Carolina storytellers, like those elsewhere, told tales in which the dominant spiritual configuration provided the means by which Africans, whatever their ethnic differences, found values proper to them when the slave trade and slavery divorced them from their homeland. Consequently, listeners in the slave community who had previously been unexposed to those tales immediately understood what was being related, irrespective of where their parents came from. ${ }^{36}$

Avey Johnson is born into this circle of black culture: her first memorable utterances are about the ring shout, and her initiatory memories are centered on the Ibos who had foreseen the tragedies of slavery and had decided to return home by walking across the ocean. As far as her grandmother is concerned, Avey's mission is to carry into the future memories of the past: "In instilling the story of the Ibos in her child's mind, the old woman had entrusted her with a mission she couldn't even name yet had felt duty-bound to fulfill" (p. 42). Avey's crisis of consciousness develops because in espousing the notion of temporality as a form of progression from the past to the future, she has forgotten her ancestral duties; now her repressed past has returned to haunt her and "her memory seemed to be playing the same frightening tricks as her eyes" (p. 57). In the moment of narration, Avey faces an interpretative problem: how can she recover the value of a past that now appears more remote from her than it was when she began pursuing the American dream?

The idea of a historical return is an important trope in Praisesong and is often proposed as a possible resolution of the crisis of temporality which grips characters like Avey Johnson. When subliminal echoes from the past force Avey to abandon her cruise ship and return to her home, she is unconsciously drawn to a Caribbean island in which the themes of return and historical continuity are inscribed into the collective memories of the people. Waking up in a Caribbean where the past still seems to be alive, Avey finds her mind cleared of the memories that repressed her Afrocentricity, "so that she had awakened . . . like a slate that has been wiped clean, a tabula rasa upon which a whole new history could be written" (p. 151). But how is this history written? Or rather, how is the subject inscribed into its founding mythology?

Again, we must remember that the so-called Carriacou excursion is, like the carnival in Bourneville, a performative act that has ensured the

36. Sterling Stuckey, Slave Culture: Nationalist Theory and the Foundations of Black America (New York: Oxford University Press, 1987), p. 10. 
survival of the past in the present by annually repeating the African circle of meanings: in the great shout and dance, family and nation are recalled and connection with the past is reestablished. Every islander identifies with a nation or with a creole culture (p. 175), and hence there are no nationless people outside this circle. In a sense, by recognizing her own place within this circle, Avey has reconnected herself with her ancestral past and covered the "hole the size of a crater where her life of the past three decades had been" (p. 196). However, a final question still remains: what is the value of this form of self-recognition? The answer is contained in a passage in which Avey tries to endow the dance of the nations with a set of determinate meanings, but discovers that the quest for an African ideal is highly paradoxical:

It was the essence of something rather than the thing itself she was witnessing. . . . All that was left were a few names of what they called nations which they could no longer even pronounce properly, the fragments of a dozen or so songs, the shadowy forms of long-ago dances and rum kegs for drums. The bare bones. The burnt-out ends. And they clung to them with a tenacity she suddenly loved in them and longed for in herself. Thoughts-new thoughts-vague and half-formed slowly beginning to fill the emptiness. [P. 240]

Historical continuity may be a desired ideal, but the dominant theme now is one of "separation and loss" (p. 244); what remains of Africa is merely the fragment of (an ideal) memory.

In the circumstances, it would be futile for the exiled Africans to recover "natural" African meanings; it is impossible to recuperate African objects of knowledge in a continuous and holistic way. However, the fragments of Africa which we see in the national dances of Carriacou are valuable because they are the only basis on which a new, black discourse can be initiated within a discursive formation bent on denying the value of black cultures. At the end of Praisesong, Avey Johnson realizes that the power of the cultural circle in Carriacou does not lie in the object it projects, but in "the unacknowledged longing it conveyed" which "summed up feelings that were beyond words, feelings and a host of subliminal memories that over the years had proven more durable and trustworthy than the history with its trauma and pain out of which they had come" (p. 245). The African fragment has value precisely because it is the central focus of the rules-both conscious and unconscious - that govern black discourse. The limit of the Western version of history is shown to be its enslavement to linear 
development, the emphasis it places on the continuity of that history initiated by Columbus, a history of repression and pain, which always seems to insist that the destiny of the Caribbean is to become European. And thus, as the women novelists discussed in the next two chapters constantly aver, the primal scene of the West Indian object is marked by the paradoxes of a society caught between colonial history and the longing for a national culture. 